\title{
Oral fluoroquinolones in the treatment of pneumonia, bronchitis and sinusitis
}

\author{
Nicole Mittmann MSc $\mathrm{PhD}^{1,2}$, Farah Jivraj BScPhm MSc ${ }^{3}$, Angelina Wong BScPhm MSc ${ }^{1}$, \\ Alice Yoon $\mathrm{MHSC}^{1}$
}

N Mittmann, F Jivraj, A Wong, A Yoon. Oral fluoroquinolones in the treatment of pneumonia, bronchitis and sinusitis. Can J Infect Dis 2002;13(5):293-300.

BACKGROUND: Despite a relatively large number of clinical studies comparing oral fluoroquinolones to one antibiotic class comparator, there is limited information on the relative efficacy of different fluoroquinolones.

OBJECTIVE: To examine the efficacy and tolerability of oral fluoroquinolones in the treatment of mild to moderate communityacquired pneumonia, acute exacerbations of chronic bronchitis and sinusitis.

METHODS: A systematic review was undertaken with a MEDLINE search for antibiotics and indications. Included studies met the following criteria: original study; random allocation to treatment groups; treatment with one of the following oral antibiotics - moxifloxacin, levofloxacin, ciprofloxacin, gatifloxacin; controlled by either placebo or an active comparator medication; double-blind, single-blind or open treatment; men and women (18 years of age and older); diagnosis of one of the three indica- tions; and treatment duration of at least three days. Outcome measures included efficacy and safety. Comparative and single arm meta-analyses were conducted. Statistical differences in antibiotic success rates were evaluated. Pooled point estimates and $95 \% \mathrm{CIs}$ for the comparative statistics (z-scores, P-values) and the single-arm analysis were examined to evaluate equivalence.

RESULTS: The results of the comparative and single metaanalyses revealed no major differences between the new fluoroquinolones. This is not surprising because the clinical studies were designed to show equivalence versus their comparators. Few comparative evaluations were conducted due to a paucity of studies. In relation to other competitors, small differences were seen. CONCLUSIONS: Results indicate that, in general, fluoroquinolones had similar efficacy, overall safety and dropout rates.

Key Words: Bronchitis; Meta-analysis; Oral fluoroquinolones; Pneumonia; Sinusitis

Résumé à la page suivante

${ }^{1}$ Pharmacoeconomic Research, HOPE Research Centre, Sunnybrook and Women's College Health Sciences Centre; ${ }^{2}$ Department of Pharmacology, University of Toronto; ${ }^{3}$ Bayer Canada Inc, Toronto, Ontario

Correspondence and reprints: Dr Nicole Mittmann, Sunnybrook and Women's College Health Sciences Centre, 2075 Bayview Avenue, E240,

Toronto, Ontario M4N 3M5. Telephone 416-480-6100 ext 1652, fax 416-480-6025, e-mail nicole.mittmann@swchsc.on.ca

Received for publication June 8, 2001. Accepted June 8, 2002 


\section{Les fluoroquinolones orales dans le traitement de la pneumonie, de la bronchite et de la sinusite}

HISTORIQUE : Malgré un nombre relativement imposant d'études cliniques comparant les fluoroquinolones orales à une classe d'antibiotiques de référence, on dispose de peu d'informations sur l'efficacité relative des différentes fluoroquinolones.

OBJECTIF : Mesurer l'efficacité et la tolérabilité des fluoroquinolones orales dans le traitement des pneumonies extra-hospitalières de bénignes à modérées, des exacerbations aiguës de la bronchite chronique et de la sinusite.

MÉTHODES : On a entrepris une interrogation systématique du réseau MEDLINE à partir des mots antibiotiques et indications. Les études ainsi recensées répondaient aux critères suivants : étude originale, assignation aléatoire au groupe traité, traitement au moyen de l'un des antibiotiques oraux suivants : moxifloxacine, lévofloxacine, ciprofloxacine, gatifloxacine; avec témoins soit sous placebo ou sous médicament de référence actif; modèle à double insu, à simple insu ou ouvert ; (hommes et femmes de 18 ans et plus); diagnostic correspondant à l'une des trois indications et durée du traitement d'au moins trois jours. La mesure des résultats portait sur l'efficacité et l'innocuité. Des méta-analyses des volets comparatifs et des volets indépendants ont été effectuées. Les différences statistiques quant au taux de réussite des antibiotiques ont été évaluées, les estimations ponctuelles regroupées et les intervalles de confiance à $95 \%$ pour les statistiques comparatives (score $z$ et valeur $\mathrm{p}$ ), de même que l'analyse des volets indépendants ont été examinés pour évaluer les équivalences.

RÉSULTATS : Les résultats des méta-analyses comparatives et indépendantes n'ont révélé aucune différence majeure entre les nouvelles fluoroquinolones. Cette conclusion n'est pas surprenante, puisque les études cliniques ont été conçues pour montrer l'équivalence par rapport aux agents de référence. Peu d'évaluations comparatives ont été effectuées en raison de la rareté des études. En ce qui a trait aux autres agents de référence, de petites différences ont été relevées.

CONCLUSION : Selon les résultats, en général, les fluoroquinolones donnent lieu à une efficacité, une innocuité globale et des taux d'abandon similaires.
$\mathrm{A}^{\mathrm{n}}$ number of fluoroquinolones are available for the treatment of upper and lower respiratory tract infections, including ciprofloxacin, moxifloxacin, gatifloxacin and levofloxacin. The antimicrobial spectrum of ciprofloxacin includes Gram-negative organisms, some Gram-positive organisms and some atypical pathogens. Moxifloxacin, gatifloxacin and levofloxacin include the same antimicrobial spectrum as ciprofloxacin, with expanded Gram-positive coverage and broader coverage of atypical pathogens (1)

Community-acquired pneumonia (CAP) is a common infection. The annual incidence of CAP in Canada is 12 persons/1000 adults (2). Severe pneumonia was the sixth leading cause of death in Canada in 1995 and was the number one cause of death from an infectious disease (3). However, the majority of patients are diagnosed with mild to moderate CAP. Patients with mild to moderate CAP are treated in an outpatient setting, where the associated mortality is only about $1 \%$ (4). Patients may experience the following symptoms: fever, cough, sputum production, evidence of pulmonary consolidation, hemoptysis, rigors and pleuritic chest pain. Streptococcus pneumoniae and Haemophilus influenzae are the two most frequently isolated typical pathogens in CAP (5). Pneumonia was characterized by Fine and colleagues (6) and divided into a five-point severity score: $\mathrm{I} / \mathrm{II}=$ mild; $\mathrm{III}=$ moderate; and $\mathrm{IV} / \mathrm{V}=$ severe.

Acute exacerbations of chronic bronchitis (AECB) are characterized by cough and sputum production, and one of the following: fever, wheezing or shortness of breath. It is a common disease that occurs in approximately 54/1000 individuals in the United States (7).

Acute maxillary sinusitis (SIN) is a condition characterized by facial pain, purulent nasal discharge, maxillary toothache, fever, headache and malaise. It can have considerable impact on morbidity, quality of life and health care resource consumption. In 1994, 4.6\% of Canadian adults were given a diagnosis of sinusitis by a health care professional (3).

Most clinical information about fluoroquinolones is obtained from published, randomized clinical trials that compare one fluoroquinolone agent with one antibiotic comparator. Despite a relatively large number of clinical studies, there is limited information on the relative efficacy of different fluoroquinolones. The objective of the present analysis was to examine the efficacy and safety of oral fluoroquinolone antibiotics in the treatment of $\mathrm{CAP}, \mathrm{AECB}$ and SIN by using a systematic review methodology.

\section{METHODS}

A systematic review of the literature was conducted.

\section{Comparators}

Fluoroquinolones included ciprofloxacin, gatifloxacin, levofloxacin and moxifloxacin.

\section{Review of clinical literature}

A comprehensive literature search for all published clinical trials of antibiotics used in the treatment of CAP, AECB and SIN was conducted. Unpublished studies were obtained from Bayer Canada Inc. A search of MEDLINE (January 1975 to March 2001) was conducted using the following MEDLINE search strategy: 'moxifloxacin', 'levofloxacin', ‘ciprofloxacin', 'gatifloxacin', 'sinusitis', 'bronchitis', 'pneumonia' and 'community-acquired infections'. The search was limited to human, English, clinical trials; clinical trial-phase 3; clinical trial-phase 4; controlled clinical trial; meta-analysis; multicentre study; or randomized controlled trial.

Manual cross-referencing and bibliographic searches of review articles were also conducted. The papers were rated for inclusion criteria. To be included in the meta-analysis, each study met the following inclusion criteria: original study; random allocation to treatment groups; treatment 
with one of the following oral antibiotics - moxifloxacin, levofloxacin, ciprofloxacin and gatifloxacin; controlled by either placebo or an active comparator medication; doubleblind, single-blind or open-label treatment; all patients, males and females, were 18 years of age or older; diagnosis of mild to moderate CAP, AECB or SIN; and treatment duration of at least three days. All nonrandomized and nonclinical trial study designs were excluded from the meta-analysis to decrease bias. Epidemiological studies (eg, case reports, cases series, case-control and cohort), abstracts, noncomparator studies, dose-finding studies, pharmacokinetic studies and single dose studies were excluded from the analysis.

\section{Clinical outcomes}

Clinical success rate was considered the primary outcome variable in the analysis. Success rate was defined as the proportion of patients who had a successful outcome and/or responded to treatment. A successful outcome was defined as patients who had an improvement in symptoms and were cured after at least three days of therapy. Success rates were reported in an intention-to-treat (ITT) population and a clinically evaluable population, when available, from the clinical trials. Safety was evaluated by examining adverse events and study dropouts. Adverse event information consisted of the total proportion of patients reporting any adverse events (both drug-related and nondrug-related). Study dropouts were assessed by examining the total proportion of patients who dropped out of the trials. Available data were extracted from all included studies, when possible. Outcomes were aggregated according to the individual antibiotics - ciprofloxacin, gatifloxacin, levofloxacin and moxifloxacin.

\section{Analysis}

The method of Cochran (8) and DerSimonian and Laird (9) was used to calculate the point estimates, weighting individual studies by sample size and variance (random effects model). Comparative and single-arm meta-analyses were conducted. The primary analysis was a comparative arm meta-analysis. In this meta-analysis, fluoroquinolones (individual agents) were aggregated according to common comparator. Because there were few clinical trials with similar comparative groups, a secondary analysis was conducted. Single-arm meta-analyses were conducted to pool the results of all quinolones, regardless of comparator agent. The single-arm meta-analysis used the same meta-analytic techniques, with modification for single-arm analysis (10). Results were reported as a pooled mean point estimate and 95\% CIs. A test of study homogeneity was calculated using the $\chi^{2}$ test. A significant difference in the homogeneity score indicated that the studies were different.

\section{RESULTS}

Comprehensive searches of MEDLINE and unpublished studies were completed. The search identified 37 papers (Table 1). Results are presented as comparative and single arm meta-analyses.

\section{Summary of comparative meta-analysis}

Only a limited number of comparative analyses could be conducted for each of the three indications. In general, no significant differences with respect to clinical outcomes were found. For CAP, one comparative analysis was conducted - moxifloxacin versus clarithromycin (Table 2). No comparative analyses were conducted for ciprofloxacin, gatifloxacin or levofloxacin, because there were no consistent comparators for those fluoroquinolones. Although, for gatifloxacin, one study compared gatifloxacin with clarithromycin, a meta-analysis could not be conducted based upon one study. There were no significant differences in outcome found between moxifloxacin and clarithromycin (ie, clinical success and failure had differences of $0.02 \%$ ).

For AECB, comparative analyses were conducted for ciprofloxacin and moxifloxacin versus clarithromycin, and a comparative analysis was done for levofloxacin versus cefuroxime (Table 2). There was no statistically significant difference in outcome rates between ciprofloxacin or moxifloxacin and clarithromycin, or between levofloxacin and cefuroxime (ie, clinical success and failure rates differed by 7.8\% $(\mathrm{P}=0.06)$ and $11.7 \%(\mathrm{P}<0.001)$, respectively $)$. One study compared gatifloxacin and clarithromycin.

For SIN, a comparative analysis was completed for levofloxacin versus clarithromycin, and for ciprofloxacin and moxifloxacin versus cefuroxime (Table 2). Again, no statistically significant differences in outcome rates were found between comparators (ie, clinical success and failure rates for levofloxacin versus clarithromycin differed by $1.6 \%$ $(\mathrm{P}=0.50)$ and $1.6 \%(\mathrm{P}=0.50)$, respectively. For ciprofloxacin versus cefuroxime, and moxifloxacin and cefuroxime, clinical success rates differed by $2.5 \%(\mathrm{P}=0.18)$ and $0.7 \%(\mathrm{P}=0.60)$, respectively. Again, while there was one study each for ciprofloxacin and gatifloxacin versus clarithromycin, a comparative analysis could not be done based on one study.

\section{Summary of single-arm meta-analysis}

Meta-analysis outcome results for each fluoroquinolone, from the aggregation of the clinical trial data according to each of the three clinical indications, are presented in Table 3. Singlearm analyses were conducted for all fluoroquinolone studies to provide point estimates for outcomes of interest. All fluoroquinolones were pooled regardless of comparator agent.

\section{CAP}

The point estimates for clinical success in clinically evaluable patients was $95.0 \%$ (no 95\% CI was available for one study) for gatifloxacin, followed by levofloxacin $(94.3 \%$, 95\% CI 91.7\% to $97.0 \%)$ and moxifloxacin $(93.9 \%, 95 \%$ CI $92.1 \%$ to $95.6 \%)$. No studies were available for oral ciprofloxacin. Because CIs for the different outcome rates overlapped, the different treatments were considered to be equivalent. CIs for dropout rate for gatifloxacin $(6.5 \%)$ and moxifloxacin (19.2\%) did not overlap. However, due to the noncomparative nature of the analysis, a difference between the agents was not determined. 
TABLE 1

Comparative and single arm meta-analyses of studies included in the MEDLINE search

\begin{tabular}{|c|c|c|c|c|c|c|}
\hline $\begin{array}{l}\text { Fluoro- } \\
\text { quinolone }\end{array}$ & CAP & Comparator & AECB & Comparator & SIN & Comparator \\
\hline Ciprofloxacin & No studies & $\mathrm{N} / \mathrm{A}$ & $\begin{array}{l}\text { Chodosh et al, } 1998(12) \\
\text { Chodosh et al, } 1998(13) \\
\text { Chodosh et al, } 1998(14) \\
\text { Cazzola et al, } 1995(15) \\
\text { Chmel et al, } 1990(16) \\
\text { Schmidt et al, } 1989(17) \\
\text { Anzueto et al, } 1998(18) \\
\text { Nouvet et al, } 1995(19) \\
\text { Davies et al, } 1986(20)\end{array}$ & $\begin{array}{l}\text { Ampicillin } \\
\text { Cefuroxime } \\
\text { Clarithromycin } \\
\text { Amox/clav, cefixime } \\
\text { Ampicillin } \\
\text { Amox/clav } \\
\text { Clarithromycin } \\
\text { Cefixime } \\
4 \text { arms of } \\
\quad \text { ciprofloxacin }\end{array}$ & $\begin{array}{l}\text { Johnson et al, } 1999(21) \\
\text { Clifford et al, } 1999(22) \\
\text { Weis et al, } 1998(23) \\
\text { Klein et al, } 1998(24)\end{array}$ & $\begin{array}{l}\text { Cefuroxime } \\
\text { Clarithromycin } \\
\text { Cefuroxime } \\
\text { Cefuroxime }\end{array}$ \\
\hline Gatifloxacin & $\begin{array}{l}\text { Ramirez et al, } \\
1999 \text { (25) }\end{array}$ & Clarithromycin & $\begin{array}{l}\text { DeAbate et al, } 1999 \text { (26) } \\
\text { Gotfried et al, } 2001 \text { (27) }\end{array}$ & $\begin{array}{l}\text { Cefuroxime } \\
\text { Clarithromycin }\end{array}$ & Fogarty et al, 1999 (28) & Clarithromycin \\
\hline Levofloxacin & $\begin{array}{c}\text { Carbon et al, } \\
1999 \text { (29) }\end{array}$ & Amox/clav & $\begin{array}{l}\text { Shah et al, } 1999 \text { (30) } \\
\text { DeAbate et al, } 1997 \text { (31) } \\
\text { Habib et al, } 1998 \text { (32) } \\
\text { Davies et al, } 1999 \text { (33) }\end{array}$ & $\begin{array}{l}\text { Cefuroxime } \\
\text { Cefuroxime axetil } \\
\text { Cefaclor } \\
\text { Cefuroxime axetil }\end{array}$ & $\begin{array}{l}\text { Adelglass et al, } 1999 \text { (34) } \\
\text { Lakso et al, } 1998 \text { (35) } \\
\text { Adelglass et al, } 1998 \text { (36) }\end{array}$ & $\begin{array}{l}\text { Amox/clav } \\
\text { Clarithromycin } \\
\text { Clarithromycin }\end{array}$ \\
\hline \multirow[t]{4}{*}{ Moxifloxacin } & $\begin{array}{l}\text { Fogarty et al, } \\
1999(37)\end{array}$ & Clarithromycin & Wilson et al, 1999 (39) & Clarithromycin & Baz et al, 1999 (42) & Trovafloxacin \\
\hline & $\begin{array}{l}\text { Meyer et al, } \\
\text { (unpublished } \\
\text { data) }\end{array}$ & Clarithromycin & Chodosh et al, 2000 (40) & Clarithromycin & Burke et al, 1999 (43) & Cefuroxime \\
\hline & $\begin{array}{l}\text { Petitpretz et al, } \\
2002(38)\end{array}$ & Amoxicillin & $\begin{array}{l}\text { DeAbate et al, } 2000 \text { (41) } \\
\text { Champlin et al, } \\
\text { (unpublished data) }\end{array}$ & $\begin{array}{l}\text { Azithromycin } \\
\text { Cefuroxime axetil }\end{array}$ & $\begin{array}{l}\text { Seigert et al, } 2000 \text { (44) } \\
\text { Littlejohn et al, } \\
\text { (unpublished data) }\end{array}$ & $\begin{array}{l}\text { Cefuroxime } \\
\text { Cefuroxime }\end{array}$ \\
\hline & & & & & $\begin{array}{l}\text { Siegert et al, } \\
\text { (unpublished data) }\end{array}$ & Cefuroxime \\
\hline
\end{tabular}

$\overline{A E C B}$ Acute exacerbation of chronic bronchitis; Amox/clav Amoxicillin/clavulanic acid; CAP Community-acquired pneumonia; N/A Not applicable; SIN Acute maxillary sinusitis

\begin{abstract}
AECB
For the single-arm analysis, the success rate for moxifloxacin was $94.2 \%$ (95\% CI $92.8 \%$ to $95.6 \%)$, followed by ciprofloxacin $(90.8 \%, 95 \%$ CI $87.7 \%$ to $94.0 \%$ ), gatifloxacin $(89.0 \%, 95 \%$ CI $85.9 \%$ to $92.1 \%)$ and levofloxacin $(84.8 \%, 95 \%$ CI $75.5 \%$ to $94.1 \%)$. Overall, the CIs for the various comparators overlapped and the treatments were considered to be equivalent. The exception to this was in clinical success rates for gatifloxacin and moxifloxacin, whose $95 \%$ CIs did not overlap, with gatifloxacin having a success rate of $89.0 \%$ and moxifloxacin having a clinical success rate of $94.2 \%$. Again, the noncomparative nature of the analysis precluded any decisions on differences.
\end{abstract}

\section{SIN}

Gatifloxacin had a clinical success rate in clinically evaluable patients of $93.0 \%$ (no 95\% CI was available for one study), followed by levofloxacin $(92.7 \%, 95 \%$ CI $88.0 \%$ to $97.5 \%)$, moxifloxacin $(90.1 \%, 95 \%$ CI $87.7 \%$ to $92.4 \%)$ and ciprofloxacin $(88.2 \%, 95 \%$ CI $84.5 \%$ to $91.9 \%)$. No significant differences were found between the treatment groups.

\section{DISCUSSION}

This was the first study to evaluate the efficacy and safety of currently available fluoroquinolones indicated for the treat- ment of CAP, AECB and SIN. In general, most comparisons were not significant. For CAP, comparative metaanalysis results showed no differences between moxifloxacin and clarithromycin in efficacy (success or failure in both the clinically evaluable and ITT populations), adverse events and dropout rates. In AECB, there were no significant differences between ciprofloxacin and moxifloxacin and comparators with respect to success and failure. Levofloxacin had a significantly lower rate of failure (clinically evaluable and ITT) than did cefuroxime. For SIN, the comparative meta-analysis results showed that levofloxacin had a significantly lower adverse event rate than did clarithromycin $(\mathrm{P}<0.01)$. The comparative analysis between fluoroquinolones and cefuroxime revealed no significant differences in success or failure rates between either moxifloxacin or ciprofloxacin and cefuroxime. There was, however, a significant difference in adverse event rate between moxifloxacin and cefuroxime (moxifloxacin $44.0 \%$ and cefuroxime $37.2 \%, \mathrm{P}=0.002$ ).

It is important to note that relatively few comparative analyses were conducted due to the absence of common comparators. Consequently, single-arm analyses were conducted. Results presented in the single-arm analysis indicated that there was general overlap of 95\% CIs between the agents in the overall clinical success rate for either the ITT 
TABLE 2

Comparative meta-analysis of fluoroquinolones for the treatment of community-acquired pneumonia (CAP), acute exacerbation of chronic bronchitis (AECB) and acute maxillary sinusitis (SIN)

\begin{tabular}{|c|c|c|c|c|c|c|}
\hline Comparison & $\begin{array}{l}\text { Success (CE) } \\
\text { Difference } \\
(95 \% \mathrm{Cl}) \\
{[\mathrm{Z}-\text { score, } \mathrm{P}]} \\
\text { (References) }\end{array}$ & $\begin{array}{l}\text { Failure (CE) } \\
\text { Difference } \\
(95 \% \mathrm{Cl}) \\
{[\text { Z-score, P] }} \\
\text { (References) }\end{array}$ & $\begin{array}{l}\text { Success (ITT) } \\
\text { Difference } \\
(95 \% \mathrm{Cl}) \\
{[\mathrm{Z}-\mathrm{score}, \mathrm{P}]} \\
\text { (References) }\end{array}$ & $\begin{array}{l}\text { Failure (ITT) } \\
\text { Difference } \\
(95 \% \mathrm{Cl}) \\
{[\text { Z-score, P] }} \\
\text { (References) }\end{array}$ & $\begin{array}{l}\text { Adverse events } \\
\text { Difference } \\
(95 \% \mathrm{Cl}) \\
{[\text { Z-score, P] }} \\
\text { (References) }\end{array}$ & $\begin{array}{l}\text { Dropout } \\
(95 \% \mathrm{Cl}) \\
{[\mathrm{Z}-\text { score, } \mathrm{P}]} \\
\text { (References) }\end{array}$ \\
\hline \multicolumn{7}{|l|}{ CAP } \\
\hline $\begin{array}{l}\text { Moxifloxacin } \\
\text { versus } \\
\text { clarithromycin }\end{array}$ & $\begin{array}{l}-0.3 \%(-3.2 \% \text { to } 2.6 \%) \\
Z=-0.21, P=0.83] \\
\text { (37; Meyer et al, } \\
\text { unpublished data) }\end{array}$ & $\begin{array}{l}0.02 \%(-2.7 \% \text { to } 2.8 \%) \\
{[\mathrm{Z}=0.01, \mathrm{P}=0.99]} \\
(37 ; \text { Meyer et al, } \\
\text { unpublished data })\end{array}$ & $\begin{array}{l}0.9 \%(-3.7 \% \text { to } 5.5 \%) \\
{[\mathrm{Z}=0.37, \mathrm{P}=0.71]} \\
\text { (37; Meyer et al, } \\
\text { unpublished data) }\end{array}$ & $\begin{array}{l}-0.9 \%(-5.5 \% \text { to } 3.7 \%) \\
{[Z=-0.37, P=0.17]} \\
\text { (37; Meyer et al, } \\
\text { unpublished data) }\end{array}$ & $\begin{array}{l}0.4 \%(-4.8 \% \text { to } 5.6 \%) \\
{[Z=0.16, P=0.87]} \\
\text { (37; Meyer et al, } \\
\text { unpublished data) }\end{array}$ & $\begin{array}{l}-1.1 \%(-5.4 \% \text { to } 3.2 \%) \\
{[\mathrm{Z}=-0.49, \mathrm{P}=0.62]} \\
\text { (37; Meyer et al, } \\
\text { unpublished data) }\end{array}$ \\
\hline
\end{tabular}

\section{AECB}

\begin{tabular}{|c|c|c|c|c|c|c|}
\hline Ciprofloxacin & $2.9 \%(-3.7 \%$ to $9.5 \%)$ & $-1.6 \%(-5.7 \%$ to $2.5 \%)$ & $1.8 \%(-2.1 \%$ to $5.8 \%)$ & $-1.6 \%(-5.3 \%$ to $2.2 \%)$ & $-0.8 \%(-9.7 \%$ to $8.2 \%)$ & Not reported \\
\hline versus & {$[Z=0.85, P=0.39]$} & {$[Z=-0.78, P=0.43]$} & {$[Z=0.90, P=0.37]$} & {$[Z=-0.81, P=0.42]$} & {$[Z=-0.17, P=0.87]$} & \\
\hline clarithromycin & $(14,18)$ & $(14,18)$ & $(14,18)$ & $(14,18)$ & $(14,18)$ & \\
\hline Moxifloxacin & $-0.21 \%(-2.8 \%$ to $2.4 \%)$ & $0.03 \%(-2.6 \%$ to $2.6 \%)$ & $1.5 \%(-2.9 \%$ to $6.0 \%)$ & $-1.5 \%(-6.0 \%$ to $1.9 \%)$ & $-4.1 \%(-9.6 \%$ to $1.4 \%)$ & $3.2 \%(-1.1 \%$ to $7.5 \%)$ \\
\hline versus & {$[Z=-0.16, P=0.88]$} & {$[Z=0.03, P=0.98]$} & {$[Z=0.68, P=0.50]$} & {$[Z=-0.68, P=0.50]$} & {$[Z=-1.45, P=0.15]$} & {$[\mathrm{Z}=1.46, \mathrm{P}=0.14]$} \\
\hline clarithromycin & $(39,40)$ & $(39,40)$ & $(39,40)$ & $(39,40)$ & $(39,40)$ & $(39,40)$ \\
\hline Levofloxacin & $7.8 \%(-0.2 \%$ to $15.9 \%)$ & $-11.7 \%(-17.3 \%$ to $-6.2 \%)$ & $4.9 \%(-1.6 \%$ to $11.4 \%)$ & $-8.7 \%(-13.2 \%$ to $-4.2 \%)$ & $3.1 \%(-0.5 \%$ to $6.7 \%)$ & $-1.4 \%(-4.7 \%$ to $1.9 \%)$ \\
\hline versus & {$[Z=1.90, P=0.06]$} & {$[Z=4.16, P<0.001]$} & {$[Z=1.49, P=0.14]$} & {$[Z=-3.81, P<0.001]$} & {$[Z=1.68, P=0.09]$} & {$[Z=-0.85, P=0.40]$} \\
\hline cefuroxime & $(30,31)$ & $(30,33)$ & $(30,31)$ & $(30,33)$ & $(30,31,33)$ & $(30,31,33)$ \\
\hline \multicolumn{7}{|l|}{ SIN } \\
\hline Levofloxacin & $1.6 \%(-3.1 \%$ to $6.3 \%)$ & $-1.6 \%(-6.3 \%$ to $3.1 \%)$ & $8.3 \%(-1.5 \%$ to $18.1 \%)$ & $-8.3 \%(-18.1 \%$ to $1.5 \%)$ & $-12.5 \%(-20.2 \%$ to $-4.8 \%)$ & $-0.6 \%(-5.1 \%$ to $3.9 \%)$ \\
\hline versus & {$[Z=0.68, P=0.50]$} & {$[Z=-0.68, P=0.50]$} & {$[Z=1.65, P=0.10]$} & {$[Z=-1.65, P=0.10]$} & {$[Z=-3.18, P=0.001]$} & {$[Z=-0.25, P=0.80]$} \\
\hline clarithromycin & $(35,36)$ & $(35,36)$ & $(35,36)$ & $(35,36)$ & $(35,36)$ & $(35,36)$ \\
\hline Ciprofloxacin & $2.5 \%(-1.1 \%$ to $6.1 \%)$ & $-3.7 \%(-9.4 \%$ to $2.0 \%)$ & $1.9 \%(-1.8 \%$ to $5.6 \%)$ & $-1.8 \%(-4.4 \%$ to $0.9 \%)$ & $2.6 \%(-1.0 \%$ to $6.2 \%)$ & $-0.8 \%(-3.2 \%$ to $1.6 \%)$ \\
\hline versus & {$[Z=1.34, P=0.18]$} & {$[Z=-1.27, P=0.20]$} & {$[Z=1.02, P=0.31]$} & {$[Z=-1.27, P=0.20]$} & {$[\mathrm{Z}=1.40, \mathrm{P}=0.16]$} & {$[Z=-0.61, P=0.54]$} \\
\hline cefuroxime & $(21,23,24)$ & $(21,23,24)$ & $(21,23)$ & $(21,23)$ & $(21,23,24)$ & $(21,23)$ \\
\hline \multirow{5}{*}{$\begin{array}{l}\text { Moxifloxacin } \\
\text { versus } \\
\text { cefuroxime }\end{array}$} & $0.7 \%(-1.8 \%$ to $3.2 \%)$ & $-0.3 \%(-4.4 \%$ to $3.9 \%)$ & $-0.6 \%(-4.1 \%$ to $3.0 \%)$ & $-0.3 \%(-4.3 \%$ to $3.6 \%)$ & $6.7 \%(2.4 \%$ to $10.9 \%)$ & $1.1 \%(-1.9 \%$ to $4.1 \%)$ \\
\hline & {$[\mathrm{Z}=0.53, \mathrm{P}=0.60]$} & {$[\mathrm{Z}=0.53, \mathrm{P}=0.60]$} & {$[\mathrm{Z}=-0.32, \mathrm{P}=0.75]$} & {$[Z=-0.16, P=0.87]$} & {$[\mathrm{Z}=3.08, \mathrm{P}=0.002]$} & {$[\mathrm{Z}=0.74, \mathrm{P}=0.46]$} \\
\hline & $(43,44 ;$ Littlejohn & $(43,44 ;$ Littlejohn & $(43,44 ;$; Littlejohn & $(43,44 ;$ : Littlejohn & $(43,44 ;$ Littlejohn & $(43,44 ;$ Littlejohn \\
\hline & et al, unpublished & et al, unpublished & et al, unpublished & et al, unpublished & et al, unpublished & et al, unpublished \\
\hline & $\begin{array}{l}\text { data; Siegert et al, } \\
\text { unpublished data) }\end{array}$ & $\begin{array}{l}\text { data; Siegert et al, } \\
\text { unpublished data) }\end{array}$ & $\begin{array}{l}\text { data; Siegert et al, } \\
\text { unpublished data) }\end{array}$ & $\begin{array}{l}\text { data; Siegert et al, } \\
\text { unpublished data) }\end{array}$ & $\begin{array}{l}\text { data; Siegert et al, } \\
\text { unpublished data) }\end{array}$ & data; Siegert et al, \\
\hline
\end{tabular}

CE Clinically evaluable; ITT Intent to treat

population or the clinically evaluable population in patients with mild to moderate CAP, AECB or SIN. The only exception to this statement was in AECB, where the $95 \%$ Cls for the clinical success rates of gatifloxacin and moxifloxacin did not overlap. An examination of the single-arm analyses generally showed an overlapping of $\mathrm{Cls}$ and point estimates for the primary outcome variable. We could not determine that one antibiotic was different from another in the single-arm analysis.
Antibiotics were equal to one another with respect to clinical success rates. It should be noted that the clinical trials used in the meta-analysis were designed to show antibiotic equivalence. It is, therefore, not surprising that no differences between the antibiotics were found.

Recently, the American College of Physicians stated that "acute rhinosinusitis resolves without antibiotic treatment in most cases. Antibiotic therapy should be reserved for patients with moderately severe symptoms who meet 
TABLE 3

Single-arm analyses for each fluoroquinolone, from the aggregation of the clinical trial data according to each of the three clinical indications

\begin{tabular}{|c|c|c|c|c|c|c|}
\hline Comparison & $\begin{array}{l}\text { Success (CE) } \\
\text { (95\% CI) } \\
\text { [\# patients, } \\
\text { \# study arms] } \\
\text { (References) }\end{array}$ & $\begin{array}{l}\text { Failure (CE) } \\
\text { (95\% Cl) } \\
\text { [\# patients, } \\
\text { \# study arms] } \\
\text { (References) }\end{array}$ & $\begin{array}{l}\text { Success (ITT) } \\
\text { (95\% Cl) } \\
\text { [\# Patients, } \\
\text { \# study arms] } \\
\text { (References) }\end{array}$ & $\begin{array}{l}\text { Failure (ITT) } \\
\text { (95\% CI) } \\
\text { [\# Patients, } \\
\text { \# study arms] } \\
\text { (References) }\end{array}$ & $\begin{array}{l}\text { Adverse events } \\
(95 \% \mathrm{Cl}) \\
\text { [\# Patients, } \\
\text { \# study arms] } \\
\text { (References) }\end{array}$ & $\begin{array}{l}\text { Dropout } \\
\text { (95\% Cl) } \\
\text { [\# Patients, } \\
\text { \# study arms] } \\
\text { (References) }\end{array}$ \\
\hline \multicolumn{7}{|l|}{ CAP } \\
\hline Ciprofloxacin & No studies & No studies & No studies & No studies & No studies & No studies \\
\hline Gatifloxacin & $\begin{array}{l}95.0 \%(\mathrm{~N} / \mathrm{A}) \\
{[184,1](25)}\end{array}$ & $\begin{array}{l}5.4 \%(\mathrm{~N} / \mathrm{A}) \\
{[184,1](25)}\end{array}$ & $\begin{array}{l}80.2 \%(\mathrm{~N} / \mathrm{A}) \\
{[217,1](25)}\end{array}$ & $\begin{array}{l}19.8 \%(\mathrm{~N} / \mathrm{A}) \\
{[217,1](25)}\end{array}$ & Not reported & $\begin{array}{l}6.5 \%(\mathrm{~N} / \mathrm{A}) \\
{[217,1](25)}\end{array}$ \\
\hline Levofloxacin & $\begin{array}{l}94.3 \% \\
(91.7 \% \text { to } 97.0 \%) \\
{[292,2](29)}\end{array}$ & $\begin{array}{l}5.4 \% \\
(2.8 \% \text { to } 8.0 \%) \\
{[292,2](29)}\end{array}$ & $\begin{array}{l}82.7 \% \\
(78.4 \% \text { to } 86.4 \%) \\
{[348,2](29)}\end{array}$ & $\begin{array}{l}17.6 \% \\
(13.6 \% \text { to } 21.6 \%) \\
{[348,2](29)}\end{array}$ & $\begin{array}{l}40.5 \% \\
(35.4 \% \text { to } 45.7 \%) \\
{[348,2](29)}\end{array}$ & Not reported \\
\hline Moxifloxacin & $\begin{array}{l}93.9 \% \\
(92.1 \% \text { to } 95.6 \%) \\
{[728,4](37 ; \text { Meyer }} \\
\text { et al, unpublished } \\
\text { data; } 38)\end{array}$ & $\begin{array}{l}6.1 \% \\
(4.4 \% \text { to } 7.9 \%) \\
{[728,4](37 ; \text { Meyer) }} \\
\text { et al, unpublished } \\
\text { data; } 38)\end{array}$ & $\begin{array}{l}78.0 \% \\
(71.9 \% \text { to } 84.2 \%) \\
\text { [893,4] (37; Meyer) } \\
\text { et al, unpublished } \\
\text { data; } 38)\end{array}$ & $\begin{array}{l}22.0 \% \\
(15.8 \% \text { to } 28.1 \%) \\
\text { [893,3] (37; Meyer) } \\
\text { et al, unpublished } \\
\text { data; } 38)\end{array}$ & $\begin{array}{l}40.8 \% \\
(29.9 \% \text { to } 51.6 \%) \\
\text { [893,3] (37; Meyer) } \\
\text { et al, unpublished } \\
\text { data; } 38)\end{array}$ & $\begin{array}{l}19.2 \% \\
(12.7 \% \text { to } 25.7 \%) \\
{[453,2](37 ; \text { Meyer })} \\
\text { et al, unpublished } \\
\text { data; } 38)\end{array}$ \\
\hline \multicolumn{7}{|l|}{ AECB } \\
\hline Ciprofloxacin & $\begin{array}{l}90.8 \% \\
(87.7 \% \text { to } 94.0 \%) \\
{[1404,8](12-19)}\end{array}$ & $\begin{array}{l}9.2 \% \\
(6.0 \% \text { to } 12.3 \%) \\
{[1404,8](12-19)}\end{array}$ & $\begin{array}{l}76.4 \\
(67.7 \% \text { to } 85.0 \%) \\
{[1871,12](12-20)}\end{array}$ & $\begin{array}{l}17.1 \% \\
(9.0 \% \text { to } 25.2 \%) \\
{[1872,12](12-20)}\end{array}$ & $\begin{array}{l}19.7 \% \\
(9.1 \% \text { to } 30.4 \%) \\
{[1608,9](13,15-20)}\end{array}$ & $\begin{array}{l}14.3 \% \\
(6.0 \% \text { to } 41.7 \%) \\
{[1743,9](12-14,} \\
16,18,20)\end{array}$ \\
\hline Gatifloxacin & $\begin{array}{l}89.0 \% \\
(85.9 \% \text { to } 92.1 \%) \\
{[390,3](26,27)}\end{array}$ & Not reported & $\begin{array}{l}76.6 \% \\
(72.7 \% \text { to } 80.5 \%) \\
{[454,3](26,27)}\end{array}$ & Not reported & Not reported & Not reported \\
\hline Levofloxacin & $\begin{array}{l}84.8 \% \\
(75.5 \% \text { to } 94.1 \%) \\
{[679,4](30-32)}\end{array}$ & $\begin{array}{l}11.7 \% \\
(3.5 \% \text { to } 19.9 \%) \\
{[538,5](30,32,33)}\end{array}$ & $\begin{array}{l}74.9 \% \\
(66.6 \% \text { to } 83.2 \%) \\
{[998,4](30-32)}\end{array}$ & $\begin{array}{l}15.2 \% \\
(2.8 \% \text { to } 27.6 \%) \\
{[844,5](30,32,33)}\end{array}$ & $\begin{array}{l}24.1 \% \\
(7.9 \% \text { to } 40.3 \%) \\
{[1082,6](30-33)}\end{array}$ & $\begin{array}{l}17.5 \% \\
(4.5 \% \text { to } 30.4 \%) \\
{[1090,6](30-33)}\end{array}$ \\
\hline Moxifloxacin & $\begin{array}{l}94.2 \% \\
(92.8 \% \text { to } 95.6 \%) \\
{[1146,6](39-41 ;} \\
\text { Champlin et al, } \\
\text { unpublished data) }\end{array}$ & $\begin{array}{l}4.8 \% \\
(2.5 \% \text { to } 7.1 \%) \\
{[1146,6](39-41 ;} \\
\text { Champlin et al, } \\
\text { unpublished data) }\end{array}$ & $\begin{array}{l}62.8 \% \\
(49.1 \% \text { to } 76.4 \%) \\
{[1719,6](39-41 ;} \\
\text { Champlin et al, } \\
\text { unpublished data) }\end{array}$ & $\begin{array}{l}16.2 \% \\
(8.5 \% \text { to } 23.9 \%) \\
{[1719,6](39-41 ;} \\
\text { Champlin et al, } \\
\text { unpublished data) }\end{array}$ & $\begin{array}{l}43.7 \% \\
(41.4 \% \text { to } 46.1 \%) \\
{[1719,6](39-41 ;} \\
\text { Champlin et al, } \\
\text { unpublished data) }\end{array}$ & $\begin{array}{l}28.5 \% \\
(17.5 \% \text { to } 39.5 \%) \\
{[1729,6](39-41 ;} \\
\text { Champlin et al, } \\
\text { unpublished data) }\end{array}$ \\
\hline SIN & & & & & & \\
\hline Ciprofloxacin & $\begin{array}{l}88.2 \% \\
(84.5 \% \text { to } 91.9 \%) \\
{[1091,4](21-24)}\end{array}$ & $\begin{array}{l}11.1 \% \\
(7.1 \% \text { to } 15.1 \%) \\
{[1092,4](21-24)}\end{array}$ & $\begin{array}{l}80.3 \% \\
(77.4 \% \text { to } 83.2 \%) \\
{[1233,3](21-23)}\end{array}$ & $\begin{array}{l}14.7 \% \\
(6.4 \% \text { to } 22.9 \%) \\
{[1233,3](21-23)}\end{array}$ & $\begin{array}{l}37.6 \% \\
(20.2 \% \text { to } 55.0 \%) \\
{[1253,4](21-24)}\end{array}$ & $\begin{array}{l}10.6 \% \\
(5.4 \% \text { to } 15.8 \%) \\
{[1234,3](21-23)}\end{array}$ \\
\hline Gatifloxacin & $\begin{array}{l}93.0 \% \\
(\mathrm{~N} / \mathrm{A}) \\
{[133,1](28)}\end{array}$ & $\begin{array}{l}7.0 \% \\
(\mathrm{~N} / \mathrm{A}) \\
{[133,1](28)}\end{array}$ & $\begin{array}{l}59.0 \% \\
(\mathrm{~N} / \mathrm{A}) \\
{[210,1](28)}\end{array}$ & $\begin{array}{l}41.0 \% \\
(\mathrm{~N} / \mathrm{A}) \\
{[210,1](28)}\end{array}$ & Not reported & $\begin{array}{l}5.0 \% \\
(\mathrm{~N} / \mathrm{A}) \\
{[210,1](28)}\end{array}$ \\
\hline Levofloxacin & $\begin{array}{l}92.7 \% \\
(88.0 \% \text { to } 97.5 \%) \\
{[466,3](34-36)}\end{array}$ & $\begin{array}{l}8.0 \% \\
(3.3 \% \text { to } 12.8 \%) \\
{[510,3](34-36)}\end{array}$ & $\begin{array}{l}84.4 \% \\
(77.5 \% \text { to } 91.2 \%) \\
{[227,2](35,36)}\end{array}$ & $\begin{array}{l}16.7 \% \\
(9.7 \% \text { to } 23.7 \%) \\
{[227,2](35,36)}\end{array}$ & $\begin{array}{l}49.0 \% \\
(-19.6 \% \text { to } 117.6 \%) \\
{[226,2](35,36)}\end{array}$ & $\begin{array}{l}11.8 \% \\
(-4.7 \% \text { to } 28.3 \%) \\
{[225,2](35,36)}\end{array}$ \\
\hline Moxifloxacin & $\begin{array}{l}90.1 \% \\
(87.7 \% \text { to } 92.4 \%) \\
{[1087,5](42-44 ;} \\
\text { Littlejohn et al, } \\
\text { unpublished data; } \\
\text { Siegert et al, } \\
\text { unpublished data }\end{array}$ & $\begin{array}{l}9.6 \% \\
(7.3 \% \text { to } 11.8 \%) \\
{[1106,5](42-44 ;} \\
\text { Littlejohn et al, } \\
\text { unpublished data; } \\
\text { Siegert et al, } \\
\text { unpublished data }\end{array}$ & $\begin{array}{l}81.5 \% \\
(74.6 \% \text { to } 88.4 \%) \\
{[1218,5](42-44 ;} \\
\text { Littlejohn et al, } \\
\text { unpublished data; } \\
\text { Siegert et al, } \\
\text { unpublished data }\end{array}$ & $\begin{array}{l}15.0 \% \\
(8.4 \% \text { to } 21.6 \%) \\
{[1238,5](42-44 ;} \\
\text { Littlejohn et al, } \\
\text { unpublished data; } \\
\text { Siegert et al, } \\
\text { unpublished data }\end{array}$ & $\begin{array}{l}37.1 \% \\
(30.1 \% \text { to } 44.1 \%) \\
{[1275,6](42-44 ;} \\
\text { Littlejohn et al, } \\
\text { unpublished data; } \\
\text { Siegert et al, } \\
\text { unpublished data }\end{array}$ & $\begin{array}{l}8.2 \% \\
(5.7 \% \text { to } 10.7 \%) \\
{[1218,5](42-44 ;} \\
\text { Littlejohn et al, } \\
\text { unpublished data; } \\
\text { Siegert et al, } \\
\text { unpublished data }\end{array}$ \\
\hline
\end{tabular}

AECB Acute exacerbation of chronic bronchitis; CAP Community-acquired pneumonia; CE Clinically evaluable; ITT Intent to treat; N/A Not applicable; SIN Acute maxillary sinusitis 
criteria for the clinical diagnosis of acute bacterial sinusitis or for those with severe rhinosinusitis symptoms" (11). It is not our intention to recommend antibiotic therapy for the treatment of sinusitis but, rather, to report on the current state of the published literature.

Limitations of this analysis included the paucity of literature, lack of common comparators, lack of extractable data and inconsistent definitions for outcomes. There were few studies examining only oral ciprofloxacin or levofloxacin in CAP. Studies in CAP examined intravenous treatment and then step-down therapy. There were limited numbers of clinical trials comparing each fluoroquinolone to a common comparative antibiotic. This paucity limited the number of comparative analyses conducted.

We recognize that there may be a number of unpublished studies available. A comprehensive search for unpublished studies would have involved access to different company databases and were, thus, inaccessible. However, unpublished studies for moxifloxacin were obtained from Bayer Canada Inc.

\section{REFERENCES}

1. King D, Malone R, Lilley S. New classification and update on the quinolone antibiotics. Am Fam Phys 2000;61:2741-8.

2. Feagan BG, Marrie TJ, Lau CY, Wheeler SL, Wong CJ, Vandervoort MK. Treatment and outcomes of community-acquired pneumonia at Canadian hospitals. CMAJ 2000;162:1415-20.

3. Statistics Canada. Selected leading causes of death by sex, Canada, 1995. Ottawa: Health Canada, 1996-7.

4. Marrie TJ, Durant H, Yates L. Community-acquired pneumonia requiring hospitalization: 5 year prospective study. Rev Infect Dis 1989;11:586-99.

5. Niederman MS, Bass JB Jr, Campbell GD, et al. Guidelines for the initial management of adults with community-acquired pneumonia: Diagnosis, assessment of severity, and initial antimicrobial therapy. American Thoracic Society. Medical Section of the American Lung Association. Am Rev Respir Dis 1993;148:1418-26.

6. Fine MJ, Auble TE, Yealy DM, et al. A prediction rule to identify low risk patients with community acquired pneumonia. N Engl J Med 1997;336:243-50.

7. Aboussoun LS. Acute exacerbations of chronic bronchitis. Postgrad Med 1996;99:89-102.

8. Cochran W. The combination of estimated from different experiments. Biometrics 1954;10:101-28.

9. DerSimonian R, Laird N. Meta-analysis in clinical research. Control Clin Trials 1986;7:177-88.

10. Einarson T. Pharmacoeconomic application of meta-analysis for single groups: Antifungal onychomycosis laquers as example. Clin Ther 1997;19:559-69.

11. Hickner JM, Bartlett JG, Besser RE, Gonzales R, Hoffman JR, Sande MA. Principles of appropriate antibiotic use for acute rhinosinusitis in adults: Background. Ann Intern Med 2001;134:498-505.

12. Chodosh S, Lakshminarayan S, Swarz H, Breisch S. Efficacy and safety of a 10-day course of 400 or 600 milligrams of grepafloxacin once daily for treatment of acute bacterial exacerbations of chronic bronchitis: Comparison with a 10-day course of 500 milligrams of ciprofloxacin twice daily. Antimicrob Agents Chemother 1998;42:114-20.

13. Chodosh S, McCarty J, Farkas S, et al. Randomized, double-blind study of ciprofloxacin and cefuroxime axetil for treatment of acute bacterial exacerbations of chronic bronchitis. Clin Infect Dis 1998;27:722-9.

14. Chodosh S, Schreurs A, Siami G, et al. Efficacy of oral ciprofloxacin vs. clarithromycin for treatment of acute bacterial exacerbations of chronic bronchitis. Clin Infect Dis 1998;27:730-8.

15. Cazzola M, Vinciguerra A, Beghi GF, et al. Comparative evaluation
Data were often not presented in an extractable format and, thus, appropriate data may have been excluded from the analysis. There was no standard way to present outcomes. This study calculated various outcome measures, namely clinical success rates with ITT and clinically evaluable patients, to capture as many important outcomes as possible. This limitation is not unique to this meta-analysis.

\section{CONCLUSIONS}

Results indicate that, in general, fluoroquinolones had similar efficacy rates, overall safety and dropout rates. More studies comparing each agent to similar comparators are needed before conclusions about differences in efficacy and safety can be drawn.

ACKNOWLEDGEMENTS: This study was funded by an unrestricted grant from Bayer Canada Inc. The authors thank Ms Caroline Kablau and Ms Sarika Singh for administrative assistance. of clinical and microbiological efficacy of co-amoxiclav versus cefixime or ciprofloxacin in bacterial exacerbations of chronic bronchitis. J Chemother 1995;7:432-41.

16. Chmel H, Emmanuel G, Lic T, Aderson L, Ireland J. A prospective, double-blind, randomized study comparing the efficacy and safety of low-dose ciprofloxacin with ampicillin in the treatment of bronchitis. Diag Microbiolog Infect Dis 1990;13:149-51.

17. Schmidt EW, Zimmermann I, Ritzerfeld W, Voss E, Ulmer WT. Controlled prospective study of oral amoxycillin/clavulanate vs ciprofloxacin in acute exacerbations of chronic bronchitis. J Antimicrob Chemother 1989;24(Suppl B):185-93.

18. Anzueto A, Niederman MS, Tillotson GS. Etiology, susceptibility, and treatment of acute bacterial exacerbations of complicated chronic bronchitis in the primary care setting: Ciprofloxacin $750 \mathrm{mg}$ BID versus clarithromycin $500 \mathrm{mg}$ BID. Clin Ther 1998;20:885-900.

19. Nouvet G, Benmessaoud K. Comparative efficacy and safety of ciprofloxacin and cefixime in the treatment of acute exacerbations of chronic bronchitis after first-line treatment failure. French Study Group. Drugs 1995;49(Suppl 2):423-5.

20. Davies B, Maesen F, Baur C. Ciprofloxacin in the treatment of acute exacerbations of chronic bronchitis. Eur J Clin Microbiol 1986;5:226-31.

21. Johnson PA, Rodriguez HP, Wazen JJ, et al. Double-blind, comparative trial of ciprofloxacin versus cefuroxime axetil in the treatment of acute bacterial sinusitis. J Otolaryngol 1999;28:3-12

22. Clifford K, Huck W, Shan M, Tosiello R, Echols RM, Heyd A. Double-blind comparative trial of ciprofloxacin in the treatment of acute bacterial sinusitis. Sinusitis Infection Study Group. Ann Otol Rhinol Laryngol 1999;108:360-7.

23. Weis M, Hendrick K, Tillotson G, Gravelle K. Multicenter comparative trial of ciprofloxacin versus cefuroxime in the treatment of acute rhinosinusitis in a primary care setting. Clin Ther 1998;20:921-32.

24. Klein GL, Whalen E, Echols RM, Heyd A. Ciprofloxacin versus cefuroxime axetil in the treatment of adult patients with acute bacterial sinusitis. J Otolaryngol 1998;27:10-6.

25. Ramirez JA, Nguyen TH, Tellier G, et al. A prospective randomized double-blind comparative study treating community-acquired pneumonia with once-daily gatifloxacin vs. twice daily clarithromycin. J Respir Dis 1999;20(Suppl 11):S40-8.

26. DeAbate CA, McIvor RA, McElvaine P, et al. Smokers treated with gatifloxacin had a high clinical cure rate: Gatifloxacin vs. cefuroxime axetil in patients with acute exacerbations of chronic bronchitis. J Respir Dis 1999;20(Suppl 11):S23-9.

27. Gotfried MH, DeAbate CA, Fogarty C, Mathew CP, Sokol WN. 
Comparison of 5-day, short-course gatifloxacin therapy with 7-day gatifloxacin therapy and 10-day clarithromycin therapy for acute exacerbation of chronic bronchitis. Clin Ther 2001;23:97-107.

28. Fogarty C, McAdoo MA, Pater RZ. The results of a randomized, double-blind, multicenter trial of gatifloxacin vs. clarithromycin in the management of acute sinusitis. J Respir Dis 1999;20(Suppl 11):S17-22.

29. Carbon C, Ariza H, Rabie WJ, et al. Comparative study of levofloxacin and amoxycillin/clavulanic acid in adults with mild-to-moderate community-acquired pneumonia. Clin Microbiol Infect 1999;5:724-32.

30. Shah PM, Maesen FP, Dolmann A, Vetter N, Fiss E, Wesch R. Levofloxacin versus cefuroxime axetil in the treatment of acute exacerbation of chronic bronchitis: Results of a randomized, doubleblind study. J Antimicrob Chemother 1999;43:529-39.

31. DeAbate CA, Russell M, McElvaine P, et al. Safety and efficacy of oral levofloxacin versus cefuroxime axetil in acute bacterial exacerbation of chronic bronchitis. Respir Care 1997;42:206-13.

32. Habib M, Gentry LD, Rodriguez-Gomes G, et al. Multicentre, randomized study comparing efficacy and safety of oral levofloxacin and cefaclor in treatment of acute bacterial exacerbations of chronic bronchitis. Infect Dis Clin Pract 1998;7:101-9.

33. Davies B, Maesen F. Clinical effectiveness of levofloxacin in patients with acute purulent exacerbations of chronic bronchitis: The relationship with in-vitro activity. J Antimicrob Chemother 1999;76(Suppl C):83-90.

34. Adelglass J, DeAbate CA, McElvaine P, Fowler CL, LoCocco J, Campbell T. Comparison of the effectiveness of levofloxacin and amoxicillin-clavulanate for the treatment of acute sinusitis in adults. Otolaryngol Head Neck Surg 1999;120:320-7.

35. Lasko B, Lau CY, Saint-Pierre C, Reddington JL, Martel A, Anstey RJ. Efficacy and safety of oral levofloxacin compared with clarithromycin in the treatment of acute sinusitis in adults: A multicentre, double-blind, randomized study. J Int Med Res 1998;26:281-91.
36. Adelglass J, Jones TM, Ruoff G, et al. A multicenter, investigatorblinded, randomized comparison of oral levofloxacin and oral clarithromycin in the treatment of acute bacterial sinusitis. Pharmacotherapy 1998;18:1255-63.

37. Fogarty C, Grossman C, William J, Haverstock D, Church D, Community-Acquired Pneumonia Group. Efficacy and safety of moxifloxacin vs clarithromycin for community-acquired pneumonia. Infect Med 1999;16:748-63.

38. Petitpretz P, Arvis P, Marel M, Moita J, Urueta J, CAP5 Moxifloxacin Study Group. Oral moxifloxacin vs high-dosage amoxicillin in the treatment of mild-to-moderate, communityacquired, suspected pneumococcal pneumonia in adults. Chest 2001;119:185-95.

39. Wilson R, Kubin R, Ballin I, et al. Five day moxifloxacin therapy compared with 7 day clarithromycin therapy for the treatment of acute exacerbations of chronic bronchitis. J Antimicrob Chemother 1999;44:501-13.

40. Chodosh S, DeAbate CA, Haverstock D, Aneiro L, Church D. Short-course moxifloxacin therapy for treatment of acute bacterial exacerbations of chronic bronchitis. Respir Med 2000;94:18-22.

41. DeAbate CA, Mathew CP, Warner JH, Heyd A, Church D. The safety and efficacy of short course (5-day) moxifloxacin vs azithromycin in the treatment of patients with acute exacerbation of chronic bronchitis. Respir Med 2000;94:1029-37.

42. Baz M, Janetti W, Sandwall P, et al. Double-blind comparative trial of moxifloxacin versus trovafloxacin in the treatment of acute sinusitis: Effectiveness and tolerability. Today's Ther Trends 1999;17:303-19.

43. Burke T, Villanueva C, Mariano H Jr, et al. Comparison of moxifloxacin and cefuroxime axetil in the treatment of acute maxillary sinusitis. Clin Ther 1999;21:1664-77.

44. Siegert R, Gehanno P, Nikolaidis P, et al. A comparison of the safety and efficacy of moxifloxacin (BAY 12-8039) and cefuroxime axetil in the treatment of acute bacterial sinusitis in adults. Respir Med 2000;94:337-44. 


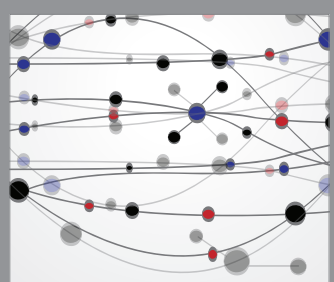

The Scientific World Journal
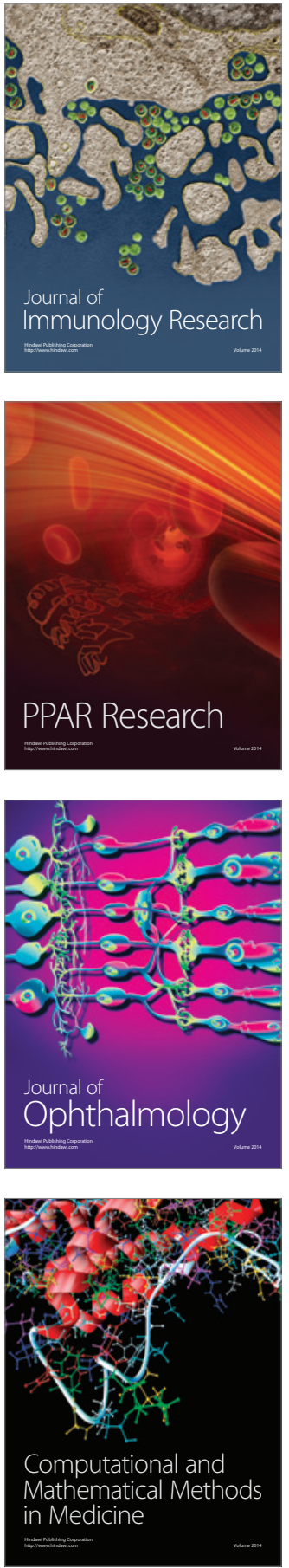

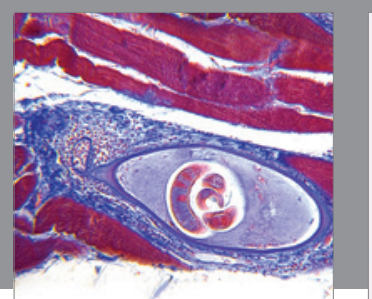

Gastroenterology Research and Practice

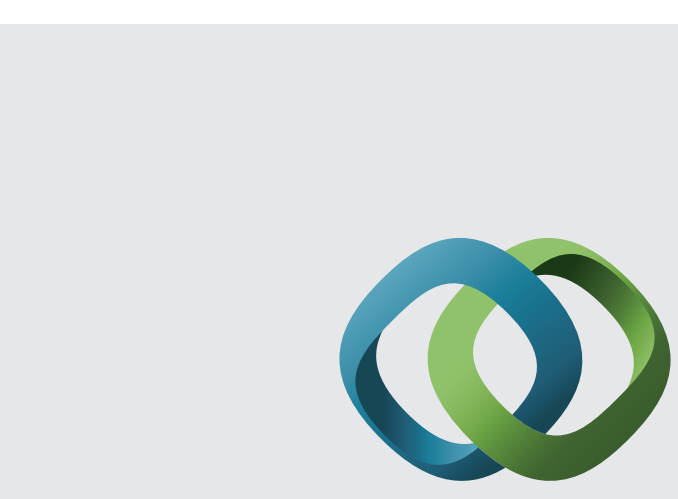

\section{Hindawi}

Submit your manuscripts at

http://www.hindawi.com
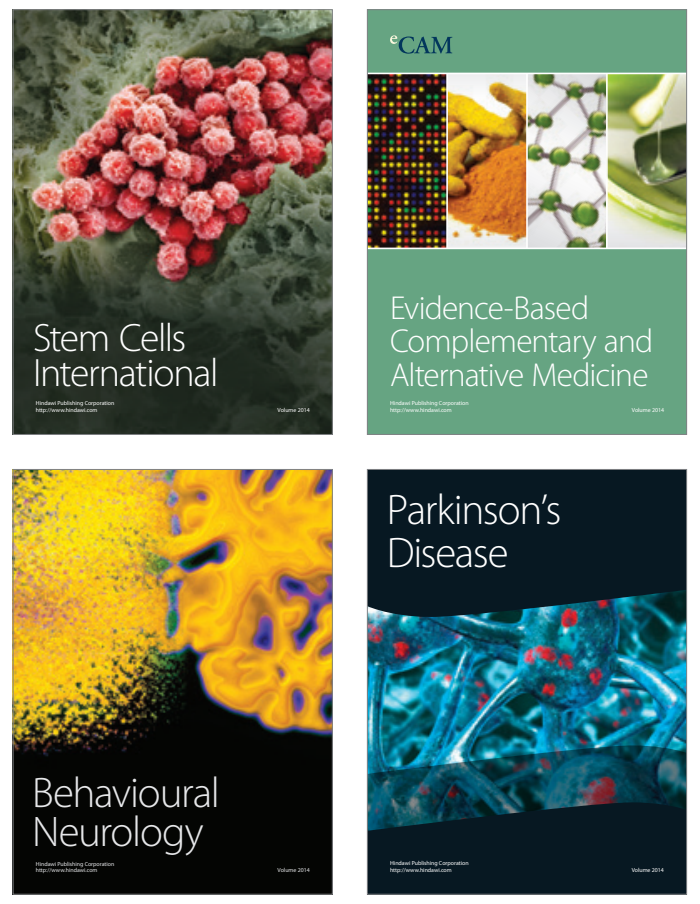
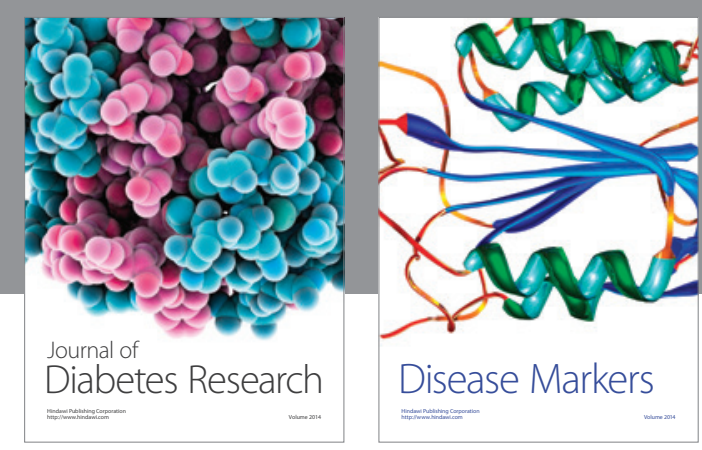

Disease Markers
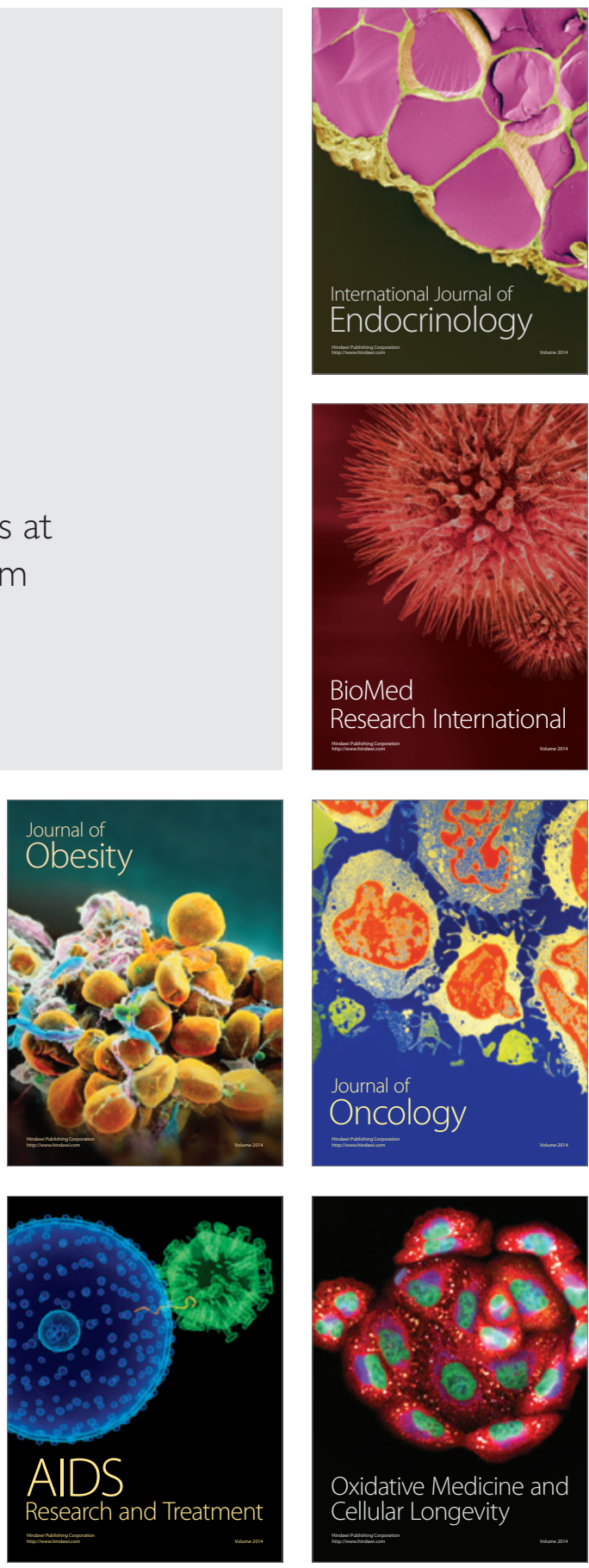